

\section{GalnInG}

UEPA

\section{experience}

\section{programme}

Are you a young psychiatrist interested in discovering different mental health systems?

The European Psychiatric Association is offering you a unique opportunity to discover renowned psychiatric institutions across Europe with a $850 €$ scholarship!

\section{APPLY NOW UNTIL 17 SEPTEMBER 2018 on www.europsy.net/gep}

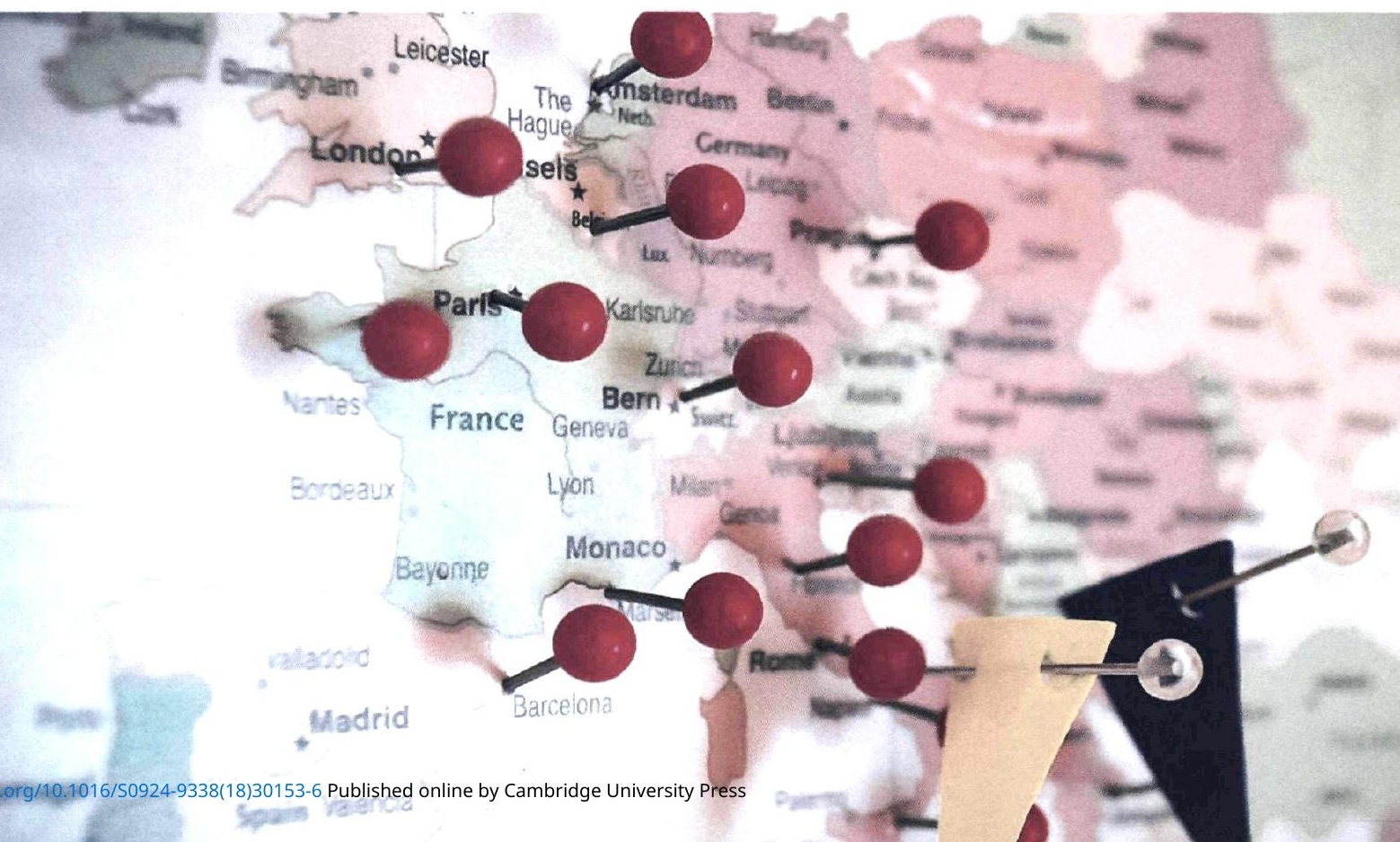




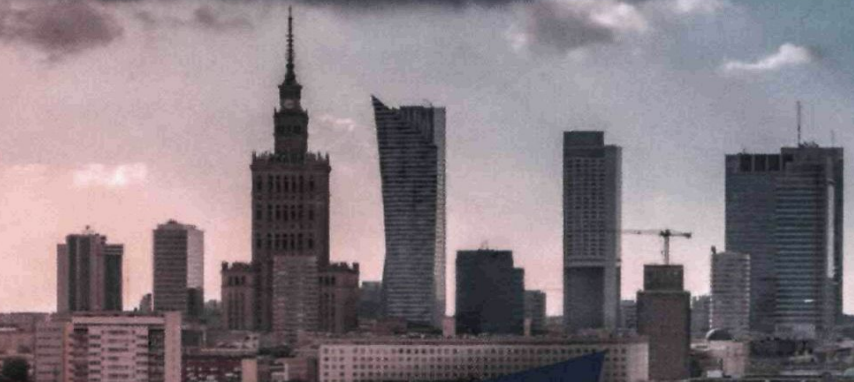

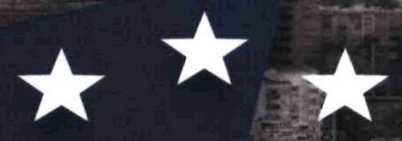

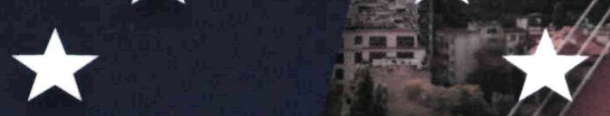

$$
\begin{aligned}
& \star \quad \star \\
& \star \quad x \\
& \star \star \text { EPA } 2019 \\
& 27^{\text {th }} \\
& \text { EUROPEAN } \\
& \text { CONGRESS } \\
& \text { OF PSYCHIATRY }
\end{aligned}
$$

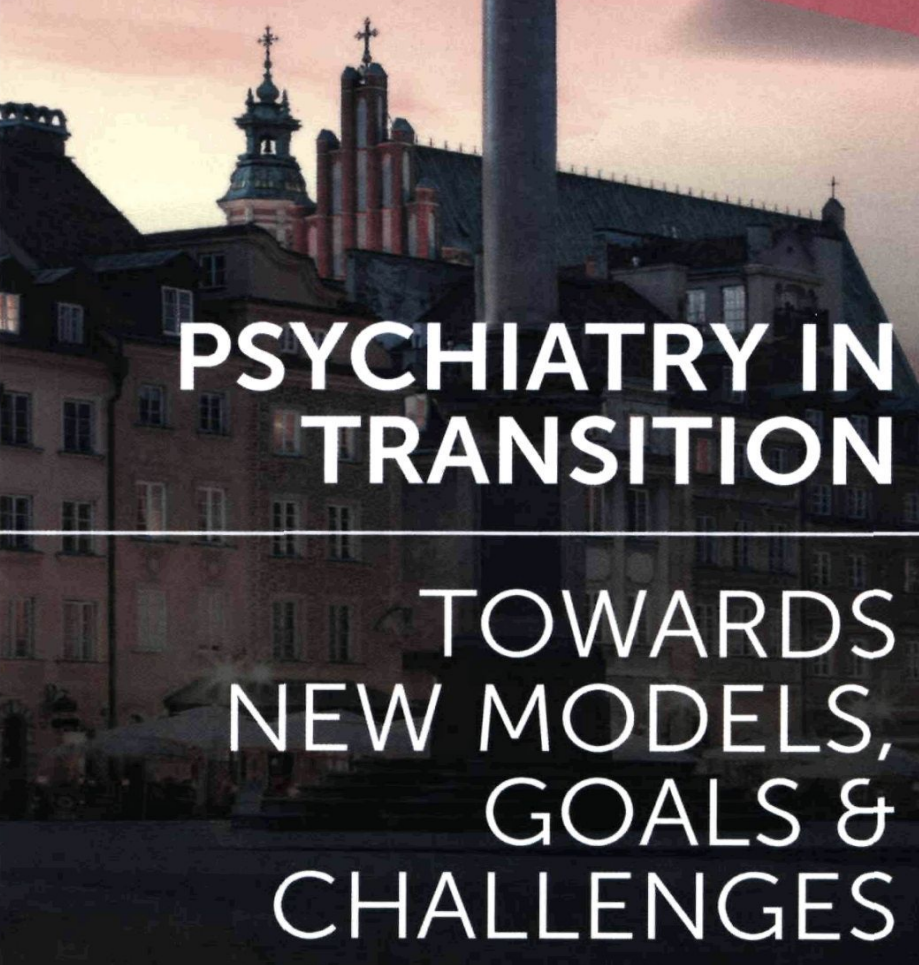

Warsaw, Poland 6-9 April 2019

Www.epa-congress.org \#EPA2019

SEE YOU THERE 
Abstracted in: BIOSIS/Biological Abstracts, Current Contents/Clinical Medicine and Social \& Behavioural Sciences, EMBASE/ Excerpta Medica, MEDLINE/Index Medicus, PASCAL/INIST-CNRS, Psychological Abstracts, PsycINFO, PsyLIT, Research Alert, SciSearch

Childhood physical maltreatment with physical injuries is associated with higher adult psychopathology symptoms

D. Lamela and B. Figueiredo

Increased risk of dementia in patients with Schizophrenia: A population-based cohort study in Taiwan C.-E. Lin, C.-H. Chung, L.-F. Chen and M.-J. Chi

Patient centric measures for a patient centric era: Agreement and convergent between ratings on The Patient Global Impression of Improvement (PGI-I) scale and the Clinical Global Impressions - Improvement (CGI-S) scale in bipolar and major depressive disorder

M. Mohebbi, S. Dodd, O.M. Dean and M. Berk

Clinical characteristics and outcomes of psychotic depression in the Northern Finland Birth Cohort 1966 M. Nietola, A. Heiskala, T. Nordström, J. Miettunen, J. Korkeila and E. Jääskeläinen

Psychopathological characteristics and adverse childhood events are differentially associated with suicidal ideation and suicidal acts in mood disorders

D. Janiri, P.D. Rossi, G.D. Kotzalidis, P. Girardi, A.E. Koukopoulos, D. Reginaldi, F. Dotto, G. Manfredi, F. Jollant, P. Gorwood, M. Pompili and G. Sani

Gut microbiome and magnetic resonance spectroscopy study of subjects at ultra-high risk for psychosis may support the membrane hypothesis

Y. He, T. Kosciolek, J. Tang, Y. Zhou, Z. Li, X. Ma, Q. Zhu, N. Yuan, L. Yuan, C. Li, K. Jin, R. Knight, M.T. Tsuang and $X$. Chen

Metacognitive Training for Depression (D-MCT) reduces false memories in depression. A randomized controlled trial S. Moritz, B.C. Schneider, J. Peth, S. Arlt and L. Jelinek

Predicting suicidal behaviour after first episode of non-affective psychosis: The role of neurocognitive functioning M. Canal-Rivero, J.D. López-Morínigo, E. Setién-Suero, M. Ruiz-Veguilla, J.L. Ayuso-Mateos, R. Ayesa-Arriola and B. Crespo-Facorro

Changes in attitude towards LAI antipsychotic maintenance treatment: A two-year follow-up study F. Pietrini, G. D'Anna, L. Tatini, G.A. Talamba, C. Andrisano, E. Calderani, M. Manetti, P. Rossi Prodi, V. Ricca and A. Ballerini

Effectiveness of watchful waiting versus antidepressants for patients diagnosed of mild to moderate depression in primary care: A 12-month pragmatic clinical trial (INFAP study)

M. Iglesias-González, I. Aznar-Lou, M.T. Peñarrubia-Maria, M. Gil-Girbau, R. Fernández-Vergel, J. Alonso, A. Serrano-Blanco and M. Rubio-Valera

Burnout in mental health professionals: A systematic review and meta-analysis of prevalence and determinants K. O'Connor, D. Muller Neff and S. Pitman

Age of onset and quality of life among males and females with schizophrenia: A national study

A. Rotstein, D. Roe, M. Gelkopf and S.Z. Levine

Value of schizophrenia treatment I: The patient journey P. Mohr, S. Galderisi, P. Boyer, D. Wasserman, P. Arteel, A. Ieven, H. Karkkainen, E. Pereira, N. Guldemond, P. Winkler and W. Gaebel 
Value of schizophrenia treatment II: Decision modelling for developing early detection and early intervention services in the Czech Republic

P. Winkler, H.M. Broulíková, L. Kondrátová, M. Knapp, P. Arteel, P. Boyer, S. Galderisi, H. Karkkainen, A. Ieven, P. Mohr, D. Wasserman, A.-L. Park, M. Tinelli and W. Gaebel .

Early life experiences and social cognition in major psychiatric disorders: A systematic review

K.I. Rokita, M.R. Dauvermann and G. Donohoe

Corrigendum to "Disability and common mental disorders: Results from the World Mental Health Survey Initiative Portugal" [Eur. Psychiatry 49 (2018) 56-61]

A. Antunes, D. Frasquilho, S. Azeredo-Lopes, D. Neto, M. Silva, G. Cardoso and J.M. Caldas-de-Almeida 


\title{
EDITORIAL LEADERSHIP
}

\section{Andrea Fiorillo}

Professor of Psychiatry, University of Campania “Luigi Vanvitelli”, Largo Madonna delle Grazie, 80138, Naples, Italy.

E-mail: andrea.fiorillo@unicampania.it

Sophia Frangou, MD, PhD, FRCPsych

Professor of Psychiatry, Icahn School of Medicine at Mount Sinai, 1425, Madison Avenue, New York, NY 10029, USA,

Tel.: (01) 212-659-1668; E-mail: sophia.frangou@mssm.edu

Reinhard Heun

Professor of Psychiatry, Radbourne Unit, Royal Derby Hospital, Uttoexter Road, Derby, DE 223WQ UK, Tel.: (44) 1332-623877;

E-mail: reinhard.heun@derbyshcft.nhs.uk

\section{EDITORIAL OFFICE}

EPA Administrative Office

15 avenue de la Liberté, 67000 Strasbourg - France

Phone: +33 388239 930; E-mail: europeanpsychiatry@gmail.com

\section{EDITORIAL BOARD}

P. Boyer (Paris), J.D. Guelfi (Paris), M. Maj (Naples), R. Murray (London), H. Sass (Aachen)

\section{STATISTICAL ADVISORS}

A. Heyting (Da Marken), N. Takei (Hamamatsu), B. Falissard (Paris)

\section{FOUNDING EDITORS}

P. Boyer (Paris), J.D. Guelfi (Paris), Y. Lecrubier (Paris)

\section{EDITORS EMERITUS}

C. Ballus (Barcelona), P. Bech (Copenhagen), C.B. Pull (Luxembourg)

\section{THE JOURNAL OF THE EUROPEAN PSYCHIATRIC ASSOCIATION}

\section{www.europsy.net}

\author{
President: S. Galderisi (Naples) \\ Past President: W. Gaebel (Düsseldorf) \\ President Elect: P. Gorwood (Paris) \\ Secretary General: J. Beezhold (Norwich) \\ Treasurer: G. Dom (Boechout) \\ Council of NPAs Chair: T. Kurimay (Budapest) \\ Secretary For Sections: M. Musalek (Vienna) \\ Secretary For Education: C. Hanon (Paris)
}

\begin{abstract}
European Psychiatry (ISSN 0924-9338) 2018 (volumes 47-54) One year, 8 issues. See complete rates at http://www.europsy-journal.com Address order and payment to Elsevier Masson SAS, Service Abonnements, 65, rue Camille-Desmoulins, 92442 Issy-les-Moulineaux cedex: payment by check or credit card (CB, MasterCard, EuroCard or Visa: indicate number and expiration date); by transfer: « La Banyue Postale ", Centre de Paris, ${ }^{\circ}$ RIB : 20041000011904540 H 02095.

Subscriptions begin 4 weeks after receipt of payment and start with the first issue of the calendar year. Back issues and volumes are available from the publisher. Claims for missing issues should be made within 6 months of publication. Includes air delivery.

Subscriptions - Tel.: (33) 0171165599 . Fax: (33) 0171165577 . http://www.europsy-journal.com

Publisher - Agnieszka Freda. Tel.: 0031612252117. E-mail: a.freda@elsevier.com

Journal Manager - Kheira Jolivet. Tel.: 33 (0) 1711650 21. E-mail: EURPSY@elsevier.com

Publishing director - Daniel Rodriguez

Author inquiries

For inquiries relating to the submission of articles (including electronic submission where available) please visit Elsevier's Author Gateway at http://authors.elsevier.com. The Author Gateway also provides the facility to track accepted articles and set up e-mail alerts to inform you of when an article's status has changed, as well as detailed artwork guidelines, copyright information, frequently asked questions and more. Contact details for questions arising after acceptance of an article, especially those relating to proofs, are provided after registration of an article for publication. Subscription conditions, instructions to authors, the contents of each issue as well as the abstracts of the articles published in European Psychiatry

are available on the journal website: www.europsy-journal.com
\end{abstract}

\section{IUEPA}

\section{Subscribe to European Psychiatry}

EPA Membership (100€) includes an online subscription to the Journal. If you are interested in becoming a member of EPA, please visit http://www.europsy.net/about-epa/individual-membership 


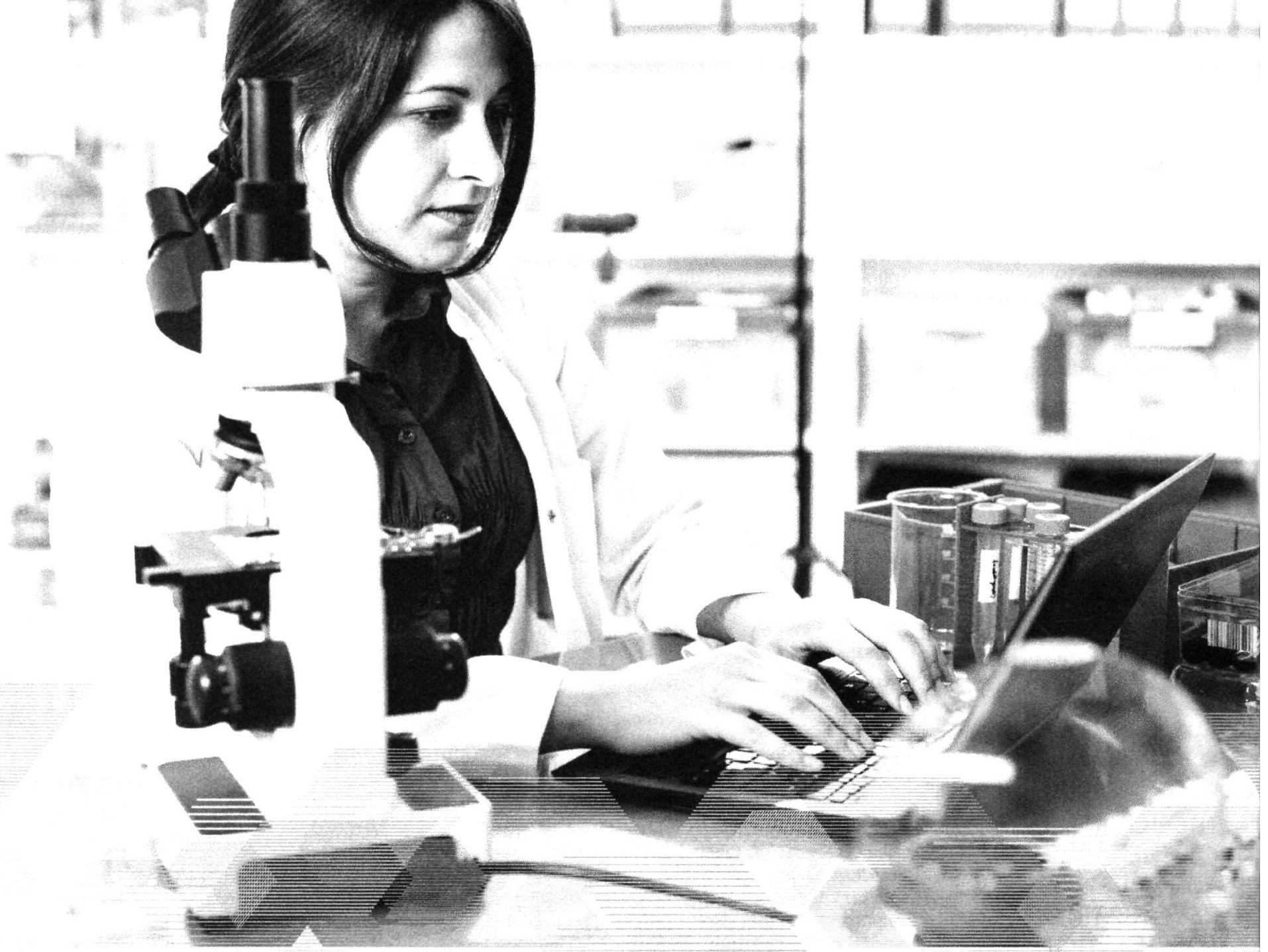

\section{Mendeley Institutional Edition}

Mendeley Institutional Edition

solutions/mendeley

www.elsevier.com/

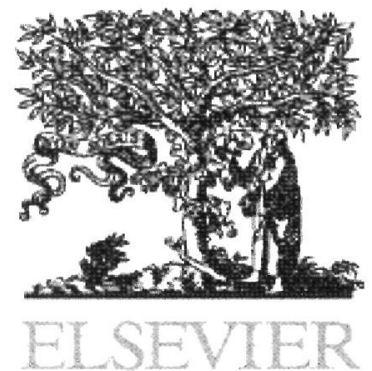


() 2018 Elsevier Masson SAS. All rights reserved.

Simplified joint stock company with sole shareholder, with a capital of $47275384 \varepsilon$ - Sole shareholder: Elsevier Holding France SAS, President: Daniel Rodriguez- Registered office: 65, rue Camille-Desmoulins, 92130 Issy-les-Moulineaux. - RCS Nanterre 542037031

This journal and the individual contributions contained in it are protected under copyright, and the following terms and conditions apply to their use in addition to the terms of any Creative Commons or other user license that has been applied by the publisherto an individual article: '

\section{Photocopying}

Single photocopies of single articles may be made for personal use as allowed by national copyright laws. Permission is not required for photocopying of articles published under the CC BY license nor for photocopying for non-commercial purposes in accordance with any other user license applied by the publisher. Permission of the publisher and payment of a fee is required for all other photocopying, including multiple or systematic copying, copying for advertising or promotional purposes, resale, and all forms of document delivery. Special rates are available for educational institutions that wish to make photocopies for non-profit educational classroom use.

\section{Derivative Works}

Users may reproduce tables of contents or prepare lists of articles including abstracts for internal circulation within their institutions or companies. Other than for articles published under the CC BY license, permission of the publisher is required for resale or distribution outside the subscribing institution or company. For any subscribed articles or articles published under a CC BY-NC-ND license, permission of the publisher is required for all other derivative works, including compilations and translations.

\section{Storage or Usage}

Except as outlined above or as set out in the relevant user license, no part of this publication may be reproduced, stored in a retrieval system or transmitted in any form or by any means, electronic, mechanical, photocopying, recording or otherwise, without prior written permission of the publisher.

\section{Permissions}

For information on how to seek permission visit www.elsevier.com/permissions or call: (+44) 1865843830 (UK) /(+1) 215 2393804 (USA).

\section{Author rights}

Author(s) may have additional rights in their articles as set out in their agreement with the publisher (more information at http://www.elsevier.com/authorsrights).

\section{Notice}

No responsibility is assumed by the publisher for any injury and/or damage to persons or property as a matter of products liability, negligence or otherwise, or from any use or operation of any methods, products, instructions or ideas contained in the material herein. Because of rapid advances in the medical sciences, in particular, independent verification of diagnoses and drug dosages should be made.

Although all advertising material is expected to conform to ethical (medical) standards, inclusion in this publication does not constitute a guarantee or endorsement of the quality or value of such product or of the claims made of it by its manufacturer.

\section{For a full and complete Guide for Authors, please refer to the World Wide Web: http://www.elsevier.com/locate/eurpsy}

\begin{tabular}{|l|l|}
\hline \multicolumn{2}{|c|}{ Information environmental / Environmental information } \\
\hline Origine du papier / Paper origin & Italie / Italy \\
\hline Pourcentage des fibres recyclées / Percentage recycled fibre & $0 \%$ \\
\hline Certification des fibres / fibre certification & $\mathrm{PEFC}$ \\
\hline Eutrophisation de l'eau / water eutrophication & $6 \mathrm{~g}$ P tonne- ${ }^{-1}$ \\
\hline
\end{tabular}

Available online at www.sciencedirect.com

\section{ScienceDirect}

European Psychiatry has no page charges 


\section{WEPA

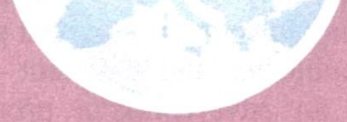

EUROPEAN

PSYCHIATRIC ASSOCIATION
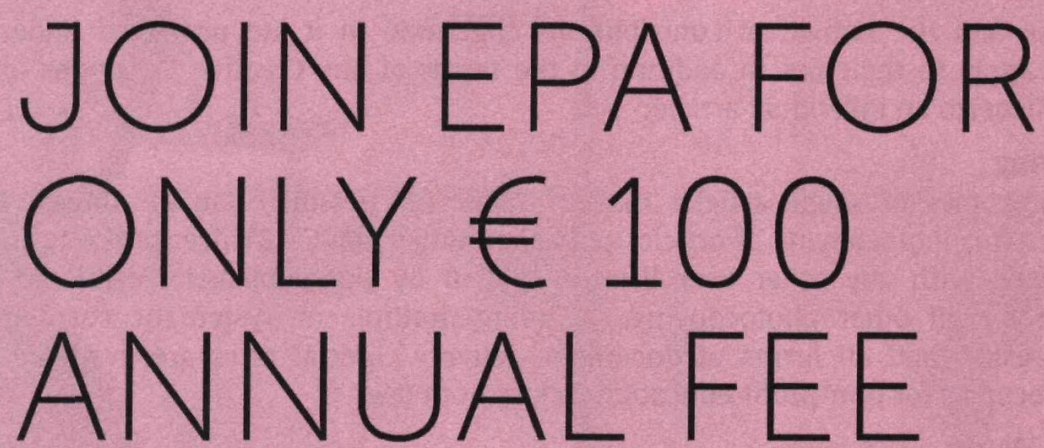

To become an individual member of the EPA, you are invited to complete an application form on the EPA website: Www.europsy.net/join-US.

\section{THE ADVANTAGES OF EPA MEMBERSHIP:}

\section{LEARN}

Keep informed about the latest

scientific research and treatments

\section{NETWORK}

Integrate the network of European practitioners and researchers in

Psychiatry

\section{CONTRIBUTE}

Get involved in the association and take an active part in the

development of Psychiatry in Europe

\section{ADVANCE}

Accelerate your career and

professional development

\section{INFLUENCE}

Have a voice and a role in shaping the future of the profession

\section{MEMBER BENEFITS:}

- Free electronic subscription to European Psychiatry journal

- Discounted registration fees for the annual European Congress of Psychiatry

- Preferential prices for EPA Courses

- An invitation to EPA General Assembly and right to vote (depending on membership category)

- Access to the EPA Extranet and member directory

- An invitation to join 22 scientific Sections

- Free monthly subscription to the EPA Minds Online newsletter

\section{FIND OUT MORE AT:

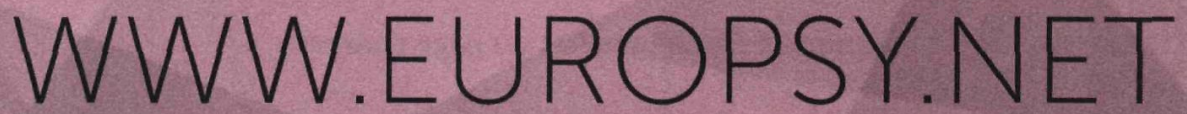

